\title{
基板検査用治具設計のための微細画像処理 システムの開発*
}

\author{
川㠃 雅生 $^{* *}$. 有木 康雄 ${ }^{* * *}$-井上 嘉明 ${ }^{* * * *}$
}

\author{
Development of a Fine-Image Processing System for Design \\ of Print Board Checking Device (Jig)
}

Masao KAWASAKI ${ }^{* *}$, Yasuo ARIKI ${ }^{* * *}$ and Yoshiaki Inout ${ }^{* * * *}$

\begin{abstract}
At present, print boad checking devices (called jig) are widely used for electrical checking of multi-layer print boards. To design these devices, it is required to extract points, which correspond to ends of electrical circuits, from the print films. The point extraction work has been done by human beings and it makes their eyes extremely tired.

This, paper describes an image processing system for newly developed for automatic point extraction, after feeding print films by one-dimensional line sensor with high resolution.

The features of the system to extract the points are :

(1) Local image processing is carried out on the large amount of data for processing efficiency.

(2) Global processing that signal connection is checked between print boards is incorporated for processing accuracy.

(3) The system is designed to be universal so that multi-layer print boards can be dealt with.
\end{abstract}

\section{1.はじめに}

プリント基板の高密度化・多層化が進む現在に扔い て, 基板製造時の精度的な問題など1) があるため, 電子 部品を搭載する前には, 基板上の回路の断線や短絡の 有無を全数検查する，いわゆる基板検查の工程がある. 検查方法としては，各基板に対応した専用の治具之呼 ばれる装置を基板でとに作成し，基板に検查用のピンを 立てて通電検查を行う方法が，一般的であり信頼性が高 い.

* 原稿受付 1993 年 10 月 13 日

** 滋賀県立機械金属工業指導所 Institute for Machine \& Metal Industry of Shiga Prefecture; 52, Okamachi, Hikone city, Shiga 522, JAPAN

*** 龍谷大学 理工学部 Faculty of Science and Technology, Ryukoku University ; 1-5, Yokotani, Oe-cho, Seta, Otsu city, Shiga 520-21, JAPAN

**** 滋賀県工業技術センタ - Industrial Research Center of Shiga Prefecture; 232, Kamitoyama, Ritto-cho, Shiga 520-30, JAPAN

Key Words : image processing, point extraction, thinning processing, connection check, AND processing.
最近の回路パターンの設計は，CAD によるあのが主 流になってはいるが，基板検查用の治具は，治具製造専 門の企業に設計を依頼して製造するのが現状であり，その 比率は $80 \%$ 以上である. その場合, CAD データを $\mathrm{MT}$ 等で直接渡すことはなく，基板製造用のプリントフィル ムを渡して，治具を設計・製造してあらうてとが多い。 このため, プリント基板製造用のフィルムから, 治具の 検查ピンをどてに立てるかを決定する作業（以下，ポイ ント取りと呼ぶ）が発生するが，乙れは，すべて人手 (目視作業) で行わ机ているが現状である.

ポイント取りとは, 具体的には，プリント基板上の回 路パターンの中から, 回路上の端点になっている部分 （ポイント）をすべて抽出する作業であり，一つの基板 では平均して 3,000 箇所程度のポイントが存在する. 多 層基板では，乙のフィルムが複数枚で全体的な回路を構 成しているため, 作業そのものあ複雑で, 熟練と根気を 要し, 平均 20 時間程度の作業がかかっている. てのた め治具設計のポイント取りに抢いては, 次のような問題 が生じている. 
(1) 作業環境の問題

平均 3,000 個のポイントをみつけるという作業量と, 1 基板当たり平均 20 時間という作業時間からくる, 目 と肉体の極度な疲労を生じる。

（2）信頼性の低下

この検査用のピンは高価であるため, 必要最小限の本 数ですべての回路パターンを検査できるように配置する 必要がある.と乙ろが，プリントフィルム上の回路パ夕 ーンは高密度であるため, その微細パターンからポイン トを抽出する作業では, 目の疲労から必ず誤りが含まれ ている．乙の誤りは人によってばらつきああるため，で きるかぎり誤りが少なく，ばらつきの少ないポイント取 りが必要とされている.

(3) 目視作業の限界

基板の多層化が進む中で, 現在 30 層クラスまでは生 産されており, 技術的には50層程度まで実用生産が可 能となってきている. これらのポイント取りを目視で行 うことは非常に困難なことであり，目視以外の手法が必 要である.

以上の点から, 本研究 ${ }^{2) ~ 4)}$ では, 基板検查用の治具設計 のために, 高密度で微細な印刷パターンを持つ複数枚の プリントフィルムから，人間の目視にかわってポイント を精度良く効率的に抽出することのできる画像処理シス テムの開発を目的としている.

画像処理システムとしては, 微細なプリントフィルム を読みとるための高解像度なラインセンサと, 読み込 まれた画像データを高速に処理するパーソナルコンピュ ータとで構成されるシステムを基本としている．1枚の プリントフィルムを通常の方式で入力すると 5,000 点 $\times$ 5, 000 行（25 M ビット）であり, 8 枚程の多層プリント フィルムでは約 $25 \mathrm{MB}$ と大容量になるため, プリント フィルムの入力, 処理方式にも精度を保持しながら処理 効率をはかるための工夫が必要である. 本研究で開発し た基板検查用治具設計のための, 大容量微細画像処理シ ステムの特徴は次のとおりである.

（i ）処理の効率をはかるために，画像全体に処理をほ ごこすことをさけ，ポイントをさがすために画像 処理の適用領域を極力限定している.

（ii）実用に耐えうる精度を得るために，複数枚のプ リントフィルムの画像間で信号線の連結関係を 調べ，真のポイントのみをとるよう処理してい る.

以下, 2. ではポイント取りの工程を画像処理として実行 する方法について述べる. 3., 4. ではシステムのハード ウエアとソフトウエアについて述べ， 5 . で処理結果につ いて述べる.

\section{2. ポイント取りの工程と自動化のための 画像処理}

\section{1 人間によるポイント取りの工程}

多層プリント基板用フィルムとして，6 層用のものを 例によって, 人間によるポイント取りの工程について概 略を述べる，6層用のプリントフィルムは，基板の表面 と裹面の信号層 (以下, S 1, S 2 層と呼ぶ), 内層の信 号層 (S 3, S 4 層), グランド層 ( $\mathrm{G}$ 層), 電源層 ( $\mathrm{V}$ 層) の 6 枚と, S 1, S 2 層に対応するレジスト層 (R 1, R 2 層）の8枚から構成されている.レジスト層とは，基板 の表面と裏面の信号層に対して，レジスト（絶縁膜）が 存在していないとてろを示すフィルムである. Fig.1 亿 6 層用プリントフィルムのレジスト層と S 1 層の一部を 示す.

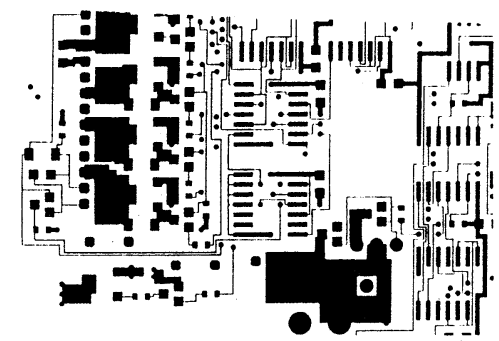

(a) A part of S1 layer

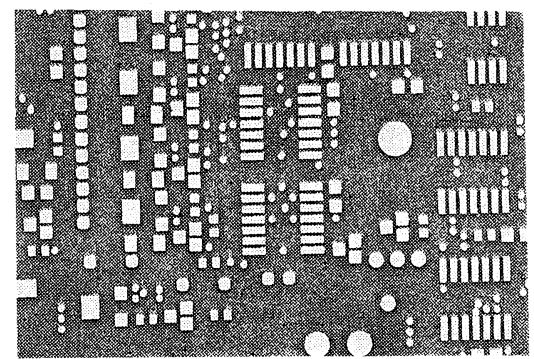

(b) A part of regist layer

Fig. 1 Example of $\mathrm{S} 1$ and regist layer

目視作業によるポイント取りの概略の工程は次のとお りである.

ステップ1 S 1 層と S 2 層を見て部品をハンダ付けする 場所，むしくは層と層を電気的に接続する ための穴（スルーホール）のある場所を見 つける.乙の場所は通常ランドと呼ばれて いる. ランドの形は千差万別である.

ステップ 2 つぎに，ランドのうち，信号の中継場所と なっているランドはポイントではないので 除外する.中継場所とは, Fig.2 (a) のよ 


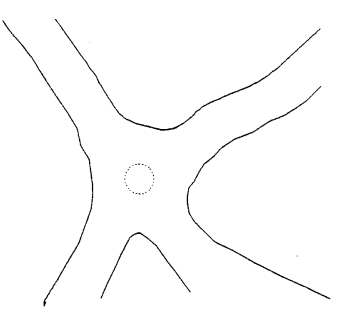

(a) Land (not point candidate)

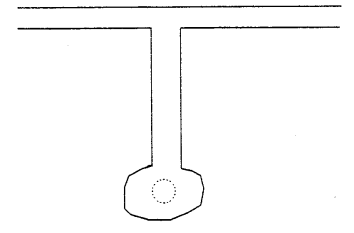

(b) Land (point candidate)

Fig. 2 Two kinds of lands

うに 2 本以上の信号線（以後乙れを手と呼 ぶ)が入りこんでいるランドのととである. てのようなランドを除外することにより，

Fig. 2 (b) のような信号線の端，すなわち 信号が行き止まりとなる所を検出するとと ができる.

ステップ 3 最後に, 残っているランドに対して層間の 結合を調べる. ての様子を Fig. 3 に示す.

Fig. 3 では, ○と(1)が対象として残ってい るランドであり, (2) は S 2 層で手を 2 本む つため, ステップ2ですでに除外されてい る. 残っているランドが S 3 層, S 4 層, グ ランド層，電源層と結合しているかどうか 調べる. (1)のように結合してい扎ば，その ランドは層間でスルーホールの采をもつた め信号線の端とはみなされないので，ポイ

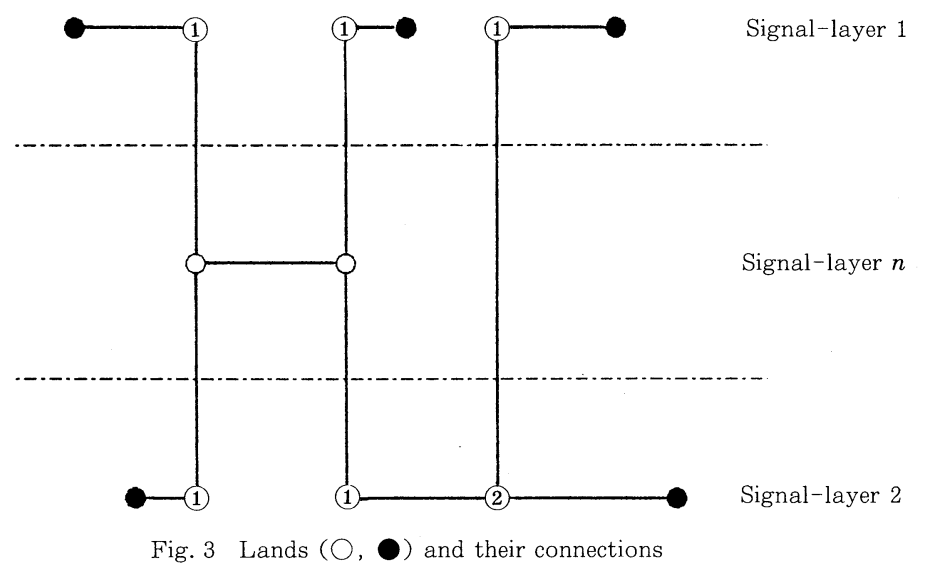

ントから除外する，乙うして，最終的に

のみがポイントとして抽出される.

\section{2 自動化のための画像処理}

人間によるポイント取りの概略工程にほぼ対応して, 処理の精度を保持しつつ処理効率を上げるために，次の ような自動化の手法を採用している，ただし，各プリン トフィルムは二值画像として入力されており, 信号線, 電源，グランドの存在しているとてろ，执よびレジスト の存在していないとてろが 1 の情報をあっているあのと する.

\section{(1) S 1 層， S 2 層とレジスト層との AND 処理}

部品をハンダ付けする場所やスルーホールの場所であ るランドの形は千差万別であるため, 人間と同様な処理 によってランドを抽出することは精度上無理がある. 本 研究では,「レジスト層で示されているレジストの無い とてろ（以後レジスト無しと呼ぶ）にのみポイントを立 てることができる」という考えから， S 1 層とレジスト 層, S 2 層とレジスト層との AND 処理を行って, 信号 線上でレジスト無しのところをランドとして検出してい る.

Fig.4 (a) は，通常の信号線とレジスト無しとの関係 を示すもので, この場合, AND 処理の結果はレジスト 無しと同じとなり，ランドが抽出される. 一方，Fig.4 (b) は, IC 部品をハンダ付けするランドの部分であり, レジスト無しと信号線との AND 処理により，簡単にラ ンドを抽出することができる．また，乙の処理は，信号 線のみからランドを抽出する目視の場合に比べて，同程 度に精度のよい処理となっている.

(2) ランドの判別処理

(1) で抽出されたランドには，2 種類のランドがある. 一つはスルーホールと呼ばれるランドであり，各層間で の接続も考慮しなければならない。あう一つは，表面 実装と呼ばれるランドであり，文字どおり表面（あしく 続用の穴があいていないため, 他の層とのつながりは無い。し たがって, ランドに接続する信 号線の数を調べる場合，スルー ホールは全層で，表面実装はそ の層のみで数える必要がある.

表面実装とスルーホールの判 別は，ランドの中心位置に打け るグランド層と電源層の存在の 有無の組み合わせで行える. Table 1 にその組み合わせとと あにランドの分類を示す。グラ 

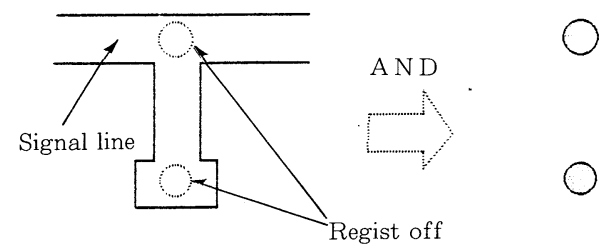

(a) Normal case

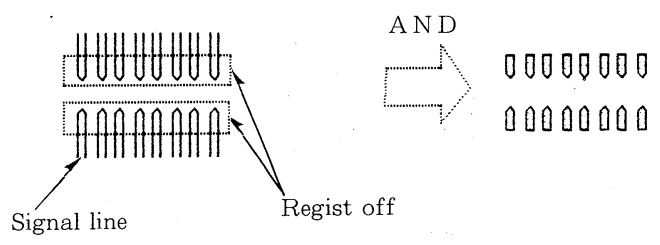

(b) In a case of IC part

Fig. 4 AND processing between regist layer and $\mathrm{S} 1 / \mathrm{S} 2$ layer

Table 1 Classification of lands

\begin{tabular}{|c|c||c|}
\hline $\mathrm{V}$ & $\mathrm{G}$ & role of lands \\
\hline 1 & 1 & Surface line \\
\hline 1 & 0 & $\begin{array}{c}\text { Through hole } \\
\text { for power }\end{array}$ \\
\hline 0 & 1 & $\begin{array}{c}\text { Through hole } \\
\text { for ground }\end{array}$ \\
\hline 0 & 0 & $\begin{array}{c}\text { Through hole } \\
\text { for signal }\end{array}$ \\
\hline
\end{tabular}

ンド層と電源層が両方 1 の場合は, その位置に S 1 層と $\mathrm{S} 2$ 層の接続は存在しないので, 表面実装と判別でき, その他の場合にはスルーホールと判別する. スルーホー ルと判別したランドについては, グランド層や電源層と の接続があれば, 手の数を一つ追加しておく.

\section{(3) ランドの近傍における信号層の細線化処理}

Fig. 5 (a) に示すように (1) で抽出されたランドの中 心に抢いて，信号線の数 (手の数) を数える. ランドの 周囲を回って信号線を横ざる回数を調べる方法は, ラン ドの大きさが千差万別であるてと，またプリントフィル ムが高密度であり, 近傍に他の信号線が存在すること, の理由により適用できない．

本研究では, 処理効率を考慮して, Fig.5 (b) のよう にランドの近傍のみに細線化処理5,6) をほどこし, 他の 信号線が存在しないランドの中心付近で 1 周することに より手の数を数えている.（2）で述べたように，スルー ホールの場合はてれをすべての信号層で行い，表面実装 の場合は S 1 層と S 2 層のみに対して行う. スルーホー ルの場合にすべての信号層で細線化して手の数を数える

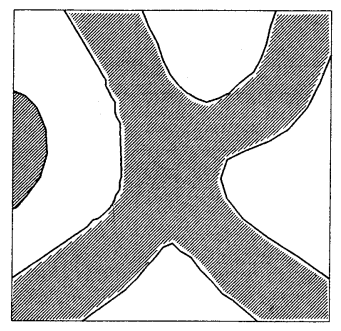

(a) Neighborhood of a land

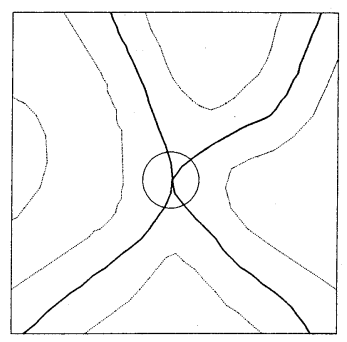

(b) Thinning processing

Fig. 5 Neighborhood of a land and thinning processing $(\mathrm{O}$ : land)

理由は，どの層にも結合していないスルーホールや S 3 層や S 4 層のみで結合しているスルーホールが存在する ためである. 最終的に手の数が 2 本以上のランドを除外 し, 手の数が 1 以下のみのランドをポイントとして抽出 する.

ランドの数は平均 10,000 個ほど存在し，また 6 層基 板であれば信号層が 4 層存在するため, 細線化に要する 処理時間は大きいが, ランドの近傍のみを細線化するこ とで処理の効率を上げている.

Fig. 6 に，多層基板用プリントフィルムを入力した場 合の処理凹流れを示す. 6 層用プリントフィルム 8 枚は, 各々, 入力装置により 2 值画像として入力される. AND 処理や層間の結合を調べる必要性から, 入力した 8 枚の 二值画像の位置合わせを行っている. その後, 先に述へ たように，レジスト層と S 1 層，レジスト層と S 2 層の AND 処理を行いランドを抽出する. 次に層間の結合を 調べた後, 細線化により各ランドに扔ける手の数を決定 しポイントを抽出する. 最後にポイントの位置を印刷出 力して終了する. 以下システムの実装方法をハードウエ アとソフトウェアに执いて述べる.

\section{3. システムのハードウェア構成}

Fig. 7 にシステムのハードウエア構成を示す.

処理装置之入力装置は, シリアルインターフェイス之 パラレルインターフェイスで接続されて扔り, 入力装置 に対するパラメータの設定や動作指示は, シリアルイン 


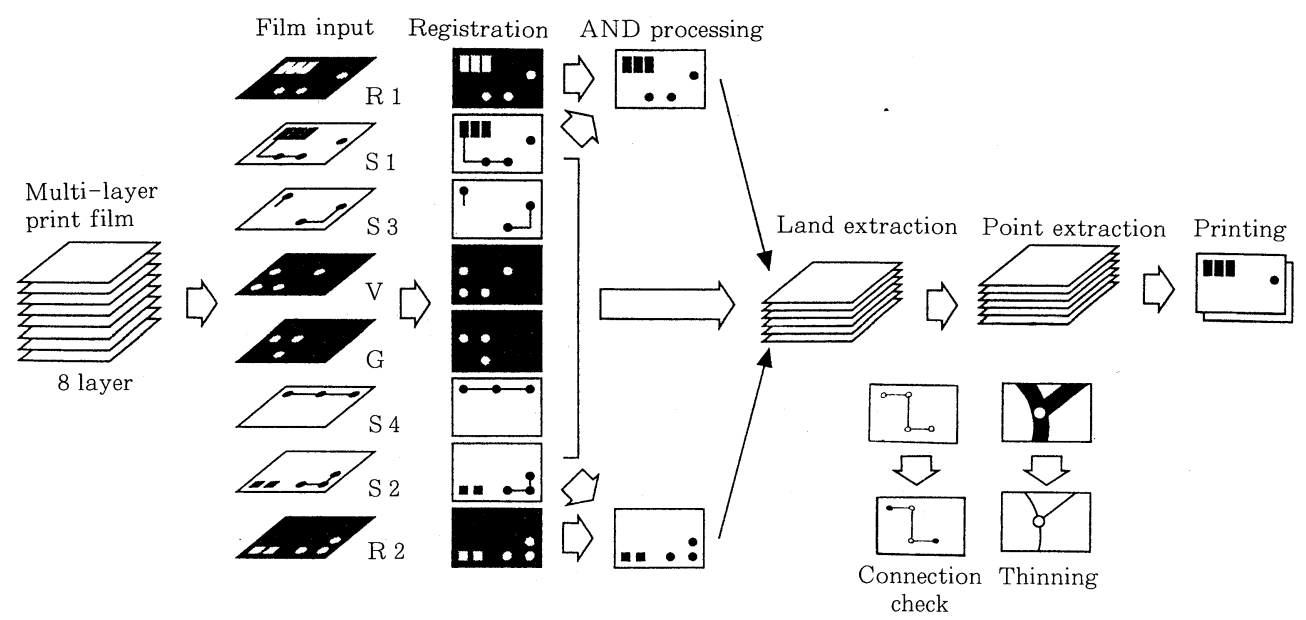

Fig. 6 Processing flow

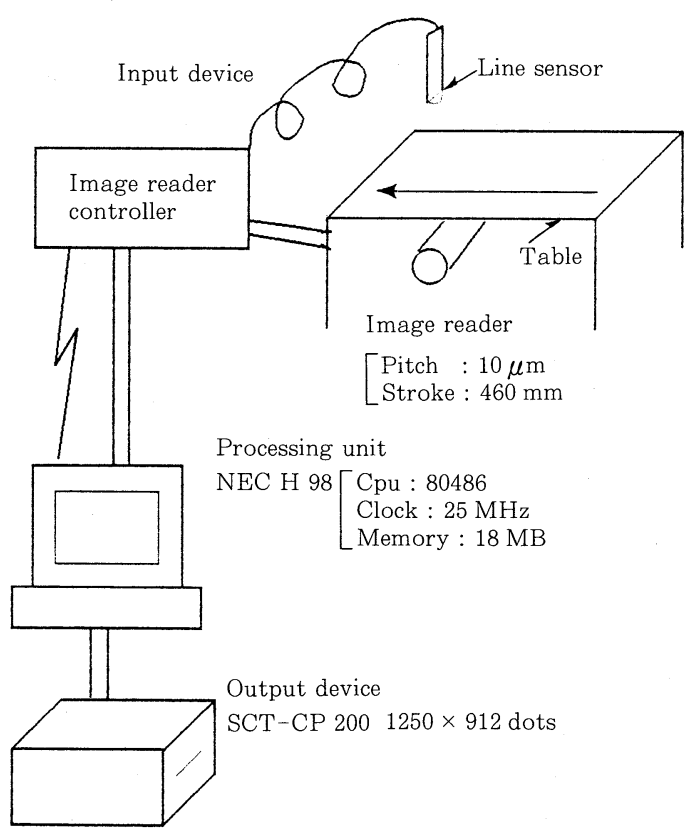

Fig. 7 Hardware organization

ターフェイスで行い, 入力データはパラレルインターフェ イスから送られてくる.

\section{1 入力装置}

フィルムパターンは, 最小の線幅が $200 \mu \mathrm{m}$ 程度であ るが, 線の両端での 1 ドットのふらつきを考えると, 最 小の線幅を 3 画素で入力できる視野を設定する必要があ る. そのためには, 1 画素の視野を $70 \mu \mathrm{m}$ 以下にしなけ ればならない。 また，実寸印刷を行う必要があるため, 1 視野でフィルム幅全体 $(275 \mathrm{~mm})$ を, 入力できる方
が望ましい．市販されている 2 次元 CCD は, $1,024 \times$ 1, 024 素子程度であり, 分解能の点で問題があるため, 本システムでは 1 次元ラインセンサを使用している. て の入力装置は，ラインセンサを使って 1 行当たり 5,000 ドットのデータを, 最高 $0.6 \mathrm{~ms}$ で入力するてとができ, 2 値化して 1 , または 0 の開始位置を 1 次元座標值の形 で格納することができる.

フィルムパターンは, 全体を平均すると 1 行当たり 100 個程度の信号線および部品装着の回路パターンを持って いるため， 1 行分のデータには，約 200 個の 1 または 0 の開始点がある.したがって 1 行当たりの記憶容量とし ては, 約 400 バイト（2 バイト/個 $\times 200$ 個）必要であり, 1 枚のフィルムパターンは, 平均約 2 メガバイトで格納 される。

\section{2 処理装置}

2.2 で述べた画像処理を高速に実行し，なおかつシス テムのコストを低く拉さえるために，処理装置として Fig. 7 に示すようなパーソナルコンピュータを使用して いる．乙の処理装置の OS としては OS $/ 2$ を使用してお り,マルチスレッド機能を用いることで後述する 4.1〜 4.3 の処理を並列に実行することができる. また，入力さ れる画像サイズが大きいことから, 主記憶として $18 \mathrm{MB}$ を搭載し，並列処理の効率を上げている.

\section{4. システムのソフトウエア構成}

Fig. 8 にシステムのソフトウエア構成を示す.プログ ラムは, MS-C で記述してあり，全体で 5, 000 ステップ 程度である。

\section{1 フィルム入力}

1 回の起動でフィルム 1 枚を, 縦方向（テーブル移動 


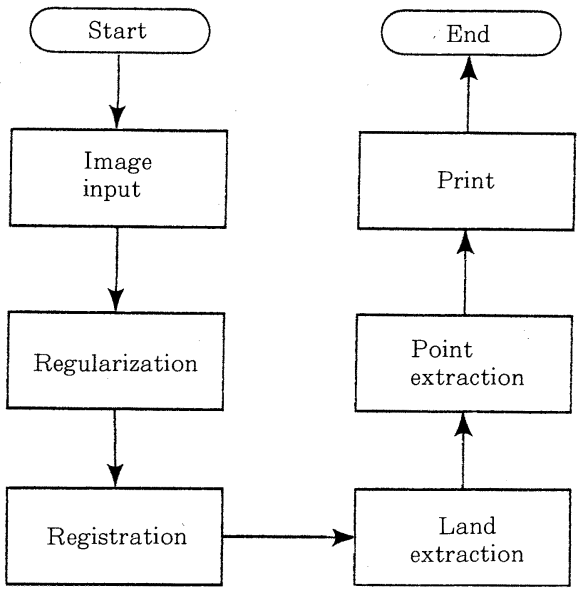

Fig. 8 Software organization

方向）に, $50 \mu \mathrm{m}$ ピッチで 5,000 行 (最高 10,000 行) 分 入力する. 入力には 1 枚当たり, 2 分程度要する（入力 された画像のととを以後パターンと呼ぶ).

読み取ったデータを処理装置に送る場合，1行でとに シリアルインターフェイスからコマンドを送信すると時 間的損失が多い。 また，フィルムの高密度な部分では， 1 行当たり 400 個程度の回路パターンが存在するため, 最大 1,600 バイト程度を, 1 行分のデータ記憶領域とし て確保する必要がある．そこで，入力装置に $2 \mathrm{M}$ バイト のメモリを搭載し, 1 回の入力指示で 1,000 行分のパ夕 ーンを読み込み，処理装置に座標値を送信するように設 定している.

\section{2 位置補正}

縦方向に $50 \mu \mathrm{m}$ ピッチでテーブルが移動するのに対 し，横方向 (ラインセンサの視野) は, 1 ドット当たりお よそ $55 \mu \mathrm{m}$ （フィルムの幅 $275 \mathrm{~mm} \div 5,000$ ドット）で あるため，横方向に 1.1 倍して 1 画素当たりの大きさを $50 \mu \mathrm{m}$ となるように補正している。 また，ラインセンサ の中央部と端部で 1 画素に対する大きさが異なっている ので，大きさを合わせるための補正屯行っている．乙れ ら位置補正㴗する時間は， 1 枚当たり約 30 秒である.

\section{3 位置合わせ}

複数枚のフィルムの間では回路パターンの大きさは等 しいが，それをとりまく周辺部の余白の大きさは一般に 不揃いである. このため, フィルムを 1 枚でとにイメー ジリーダのテーブル上にセットして入力する場合，各フィ ルムの対応する場所がずれる（平均士 $5 \mathrm{~mm}$ 程度）とい う問題が生じる．本システムでは，画像間の AND 処理 や，画像間での信号線の結合関係を調べる必要があるの で，画像間の位置合わせを行っている.

各フィルムは，目的により周辺部に異なった文字や図
柄等を含むため，各フィルムパターン上で位置合わせの ための対応点を自動的に見つけることは，実用上精度が 期待できない，そこで， $\mathrm{G}$ 層を基準とし，その他のパ夕 ーンをディスプレイ上に表示し，両方のパターンの共通 ランドを 2 箇所マウスで指定している，指定された，対 応する 2 点の 2 次元座標値の組をむとに, 回転と平行移 動を伴う（1）式の線形変換により，座標変換を行う.

$$
\boldsymbol{p}=A \boldsymbol{q}+\boldsymbol{C}
$$

ただし，

$$
\begin{aligned}
& \boldsymbol{p}=(x, y)^{\mathrm{T}}: \text { 変換前の座標値 } \\
& \boldsymbol{q}=(X, Y)^{\mathrm{T}}: \text { 変換後の座標值 }
\end{aligned}
$$

であり, こてで,

$$
\begin{aligned}
& A=\left[\begin{array}{cc}
\alpha & \beta \\
-\beta & \alpha
\end{array}\right], \\
& \alpha=\frac{\boldsymbol{R} \cdot \boldsymbol{r}}{\|\boldsymbol{r}\|^{2}}, \quad \beta=\frac{\|\boldsymbol{R} \times \boldsymbol{r}\|}{\|\boldsymbol{r}\|^{2}}, \\
& \boldsymbol{R}=\boldsymbol{p}_{1}-\boldsymbol{p}_{2}, \quad \boldsymbol{r}=\boldsymbol{q}_{1}-\boldsymbol{q}_{2}
\end{aligned}
$$

とする．ただし， $p_{1}, p_{2}, q_{1}, q_{2}$ は 2 枚の画像に扔いて マウスで指定した 2 次元座標ベクトルであり，また，

$$
\boldsymbol{C}=-A \boldsymbol{q}_{1}+\boldsymbol{p}_{1}
$$

である。

\section{4 ランド抽出}

パターンに含まれる画像は，二值画像にすると， $25 \mathrm{M}$ バイト $(5,000$ ドット/行 $\times 5,000$ 行 $\times 8$ 枚)であるため, 全パターンに対してランド抽出処理を行うことは, 無駄 である，そてで, $2.2(1)$ で述べたように，ランド抽出 の精度と処理効率の向上を考えて, レジスト層と S 1 層, レジスト層と S 2 層との AND 処理を行う.

検查用のピンを立てて意味があるのは，ピンを立てた 部分にレジスト (絶縁膜) が存在しないところのみであ るため, ての処理により抽出されたランドには，すべて のポイントが含まれていることになる.

\section{5 ポイント抽出}

ランド抽出処理を行ったパターンと, S 1 S S 層, G 層，扰よび $\mathrm{V}$ 層よりポイント抽出を行う。

各ランドに接続している配線数，すなわち「手」の数 を調べて，ポイントを検出する．2.2 (2) で述べたよう に，ランドがポイントであるかどうかは，ランドから延 びる「手」が層内，層間で 1 本以下か 2 本以上かで区別 できる．1 本以下の場合がポイントであり，2 本以上の場 合は検査ピンを省略できるランドである.

また, 2.2 (3) で述べたように, ランドから延びる「手」 の数を正確に調べるために, 細線化を行っている. しか 
し，乙れをパターン全域に施すと，莫大な処理時間がか かるので，ランドに関するおよその大きさから決定でき る近傍領域に対して, 対象とするランドを中心位置に置 いて，局所的な細線化を施している.

\section{6 印 刷}

4.5 で抽出した検査用ピンを立てるポイントの位置を, S 1 層やS 2 層とともに色分けして印字する.

使用しているプリンタの解像度が低いため $(1,250 \times$ 912 ドット/枚), 画像の解像度を下げて出力している. このポイントの出力画像は, 確認作業に使用するため, 解像度の低さは問題とならない.

\section{5. 処理結果亡考察}

開発した本システムの有効性を確かめるために, 6 層 基板のプリントフィルム 62 サンプルに対して, システ ムによりポイント取りの処理を行った. Fig.9 (a), (b) にポイント抽出結果の一例を示す.

表面実装と呼ばれているランドは，ほとんどが細長い 長方形である. ランドの中央にある白丸は，ポイントの 位置を示す. 白丸のないランドは層内, 層間で 2 本以上 の手をあつあので, ポイントを省略できるランドである. 処理時間は，全体で 4 時間程度である. このうち作業者 がフィルムを任意の順序で 8 枚入力して, マウスにより 位置合わせのための 2 点を指定するまでの拘束時間は,

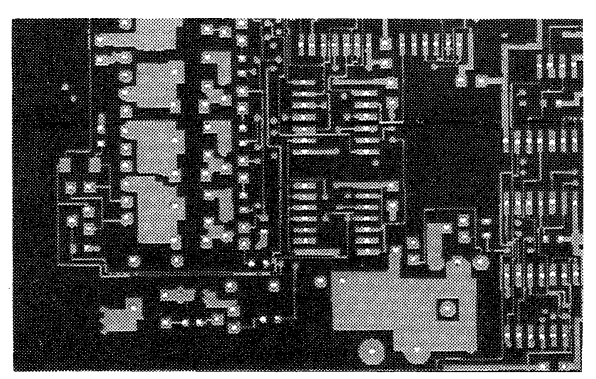

(a) S1 layer

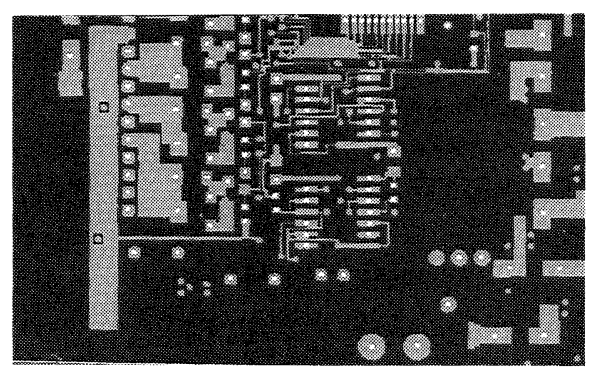

(b) S2 layer

Fig. 9 Example of extracted points (white points)
約 30 分程度である. 位置合わせは約 70 分, ランド抽出 は約 20 分, ポイント抽出は約 100 分, 印刷は約 20 分を 要する.

実用化の目安として最む重要な抽出精度については, 実験の対象としたプリントフィルム 62 サンプルの場合, 目視作業で抽出されるポイント総数 183,555 個に対して, 本システムによる自動抽出の結果は総数 183, 082 個であ り, $99.7 \%$ 以上の精度が得られた. 抽出されなかった 473 個のポイントは, フィルムの污れ（傷, ゴミ）によ り二つの回路が接続しているかのように入力されたもの や，入力テーブルの振動によるフィルムの読み取り不良 によるものなどであった，な技，本システムによって抽 出されなかったての $0.3 \%$ 弱のポイントについては, 目視作業の場合と同様，人手によって再度チェックを行 いポイント取りを完全なものとしている.

今回開発したシステムは, 6 層 (8枚組) のフィルムを 対象にしたものであるが, 5 層以下や 7 層以上のフィル ムに適用するてとあ容易であり，層数に対して汎用的な システムとなっている.

\section{6. おわりに}

本システムの開発により, 従来の目視による方法に比 較して, 下記の改善が実現できた。

(1) 作業環境の改善

作業量 (約 10,000 個のランドから 3,000 個のポイント を探索) と作業時間 (平均 20 時間程度) から来る, 目や 肉体の疲労を大幅に軽減することができた。

（2）信頼性の向上

高解像度 $(5,000 \times 5,000$ ドット) で処理することによ り, 肉眼では作業しにくい微細パターンに対しても, 高 い精度で処理できるようになった. とくに，LSI 等の単 純高密度部分に打いては, 目視ではミスが発生しやすい が，その心配がなくなった。

(3) 作業対象の拡大

基板の多層化が進む中で, 現在 30 層クラスまでは生 産されており，技術的には50 層程度まで実用生産が可 能となってきている，乙れらのポイント取りを目視で行 うことは非常に困難なことであるが，本システムは比較 的容易に実行できる.

ただし, 本システムは, ポイント取りに必要な機能の かなりの部分を含んでいるが，現場で行われている作業 ルールをすべてカバーしているわけではない. たとえば, 特殊なケースとして存在する網目状のランドに対する処 理などは, 現在のシステムに含まれていない. この点に ついては, 今後, 必要に応じて作業ルールをシステムに 追加していく予定である. 
なお，本システムは，大西電子 (滋賀県) にて，1993 年 4 月より実機として稼㗢している.

\section{参 考 文 献}

1) 栗村 : パターン欠陷検査; 精密機械, Vol. 51, No. 12, pp. $2206 \sim 2212$ (1985)

2) 川㠃, 木村, 桜井, 井上, 中川 : 検査作業の自動化のため の視覚システムの研究 (第一報); 滋賀県工業技術センター 研究報告, pp. 17〜22 (1990)

3) 川㠃, 有木, 中川 : 検查作業の自動化のための視覚システ ムの研究 (第二報); 滋賀県工業技術センター研究報告, pp. $9 \sim 13$ (1991)

4) 有木, 川㠃, 加藤, 中川 : 基板検査用治具設計のための画 像処理システム; 第 4 回インテリジェントFA シンポジゥ ム講演論文集, pp. 17〜20 (1993)

5)画像処理ハンドブック編集委員会（編）：画像処理ハンド ブック, 昭晃堂, pp. 317〜319 (1989)

6) 尾崎, 谷口: 画像処理一その基礎加ら応用まで, 共立出版, pp. 223 224 (1988) 